\title{
Cardiac Lead Function Indicator
}

National Cancer Institute

\section{Source}

National Cancer Institute. Cardiac Lead Function Indicator. NCI Thesaurus. Code

C101238.

An indicator to describe whether the electrical lead device is performing as intended.

(ACC) 